\title{
Studies on the Regulation of Glucose-metabolizing Enzymes in Bacillus subtilis
}

\author{
By V. MOSES AND PAMELA B. SHARP \\ Laboratory of Chemical Biodynamics and Lawrence Radiation Laboratory, \\ University of California, Berkeley, California, 94720, U.S.A.
}

(Accepted for publication I4 February 1968)

\begin{abstract}
SUMMARY
The presence or absence of regulatory control mechanisms has been studied for the enzymes 6-phosphogluconate dehydrogenase, glucose 6-phosphate dehydrogenase and hexokinase in Bacillus subtilis. The cellular levels of these enzymes have been investigated during steady exponential growth in various media and following growth shifts. Comparison has been made of the behaviour of these enzymes with that of $\beta$-galactosidase in a strain of Escherichia coli in which the regulator and operator genes are deleted. Criteria for recognizing truly constitutive enzymes are discussed, and it is tentatively concluded that while the synthesis of the dehydrogenases is controlled, that of hexokinase is probably constitutive.
\end{abstract}

\section{INTRODUCTION}

Nearly forty years ago Karström ( I930) distinguished between two classes of enzymes in micro-organisms. Those which were always present regardless of the growth conditions were termed 'constitutive', and although the content of such enzymes within the cells was found to differ in different media, the extents of the variations were small. By contrast, 'adaptive' enzymes were formed in response to a definite factor in the environment, and their concentrations changed very greatly in cells cultured in varying conditions. Subsequent studies have shown that the synthesis of some adaptive enzymes is stimulated as much as 1000 -fold by inclusion of appropriate substances in the medium. In other cases a less marked change is observed, amounting perhaps to a tenfold difference.

The years following Karström's publication have witnessed an intensive study of the mechanism of enzyme adaptation, culminating in a number of models which have been proposed to account for the mechanisms controlling the rates of enzyme synthesis. It is clear that the control is, at least in some cases, negative in character (Jacob \& Monod, I96I), with specific regulator molecules responding to appropriate small effector molecules in such a way as to prevent the formation of the related enzyme. From some of these controlled systems constitutive mutants have been isolated in which damage to the normal regulatory mechanism has resulted in synthesis of the enzyme independently of the presence or absence of effector molecules. Other types of less specific regulation are recognized which lead to the failure of enzyme synthesis even though the specific inducing effector molecule is present. Many catabolic enzymes are sensitive in this way to an imbalance in the over-all metabolic state of the cell, a condition designated 'catabolite repression' by Magasanik (I96I). Catabolite 
repression is observed with wild-type cells possessing an intact regulator system, and with mutants in which part of the regulatory system is non-functional (Brown, 196I ; Mandelstam, I962; Moses \& Prevost, 1966). In other mutants totally devoid of the regulatory system, part of the catabolite repression response is absent (Palmer \& Moses, I967).

There is some reason to believe that in addition to constitutive strains isolated by artificial selection procedures in the laboratory there also exist in nature wild-type constitutive systems in which the synthesis of certain enzymes might be outside the control of specific regulators. Pardee \& Beckwith (1963), in discussing the control of constitutive enzymes, have considered four possible explanations to account for such cases: (i) inducer and (catabolite) repressor are both absent; (ii) inducer is present in constant amount, and repression is absent; (iii) inducer is absent while repression is constantly effective; (iv) induction and repression are always in balance, thus permitting a constant rate of enzyme synthesis irrespective of physiological state. Pardee \& Beckwith (1963) briefly discussed a number of enzymes which might truly be constitutive in wild-type strains, but recognized the difficulty of deciding among the above four possible reasons for constitutivity and pointed out the need for further study of these and other examples.

The phenomenon of wild-type constitutivity is of fundamental biological interest. A cell which lacks a means of controlling the synthesis of certain of its components has, compared with its neighbours, an element of inflexibility which sooner or later is likely to prove of selectional importance. Thus, constitutivity based on the absence of both inducing and repressing factors has a biological significance different from constitutivity depending on a balance of these influences, since in the latter case further study might elucidate conditions under which the balance may change and alter the rate of enzyme synthesis.

The problem appeared to us of sufficient interest to warrant further investigation. The glucose-metabolizing enzymes of Bacillus subtilis were selected for study because glucose metabolism is usually regarded as being a constitutive function and the enzymes themselves are simple to measure in this organism.

\section{METHODS}

Organisms. For most of these studies a prototrophic non-sporogenic strain of Bacillus subtilis was used which was obtained from the Department of Bacteriology, University of California, Berkeley. For comparative purposes use has also been made of Escherichia coli $\mathrm{O}_{67}^{c}$ (from E. Steers) which carries a total deletion of the regulator and operator genes of the lac operon (Steers, Craven \& Anfinsen, 1965).

Media and growth measurements. Cells were grown at $37^{\circ}$ in the following media with stirring: minimal medium 63 (Pardee \& Prestridge, 196I) supplemented with $0.2 \%(\mathrm{w} / \mathrm{v})$ of the appropriate carbon source; glucose-tris minimal medium containing 0.7 mM- $P_{i}$ (Moses, 1967); glutamate-minimal medium (Hartwell \& Magasanik, 1963); and nutrient broth (Difco). Growth was followed by turbidity; at an extinction of $\mathrm{I} \cdot 0$ in a I cm. cuvette at $650 \mathrm{~m} \mu, \mathrm{I} \mathrm{ml}$. of bacterial suspension contained $225 \mu \mathrm{g}$. $/ \mathrm{ml}$. of bacterial protein (Moses \& Prevost, 1966).

Measurements of enzyme activities. In preliminary studies on the assay techniques for the three glucose enzymes it was found that some procedures for destroying the 
cellular permeability barrier inactivated hexokinase but not the dehydrogenases for glucose 6-phosphate and 6-phosphogluconate. For example, treatment with toluene, which is a standard procedure in the assay of $\beta$-galactosidase in Escherichia coli and histidase in Bacillus subtilis, totally inactivated hexokinase. Lysis of B. subtilis by lysozyme in the absence of glucose also resulted in a low activity of hexokinase. This was discovered in shift experiments of the type to be reported below. There was a large discontinuous increase in the measured activity of hexokinase in samples of the cultures taken immediately after the addition of glucose to cells growing on another substrate. This was not due to a sudden synthesis of hexokinase, as the following experiment shows.

Cells growing exponentially on nutrient broth were treated with chloramphenicol ( I $00 \mu \mathrm{g} . / \mathrm{ml}$.). Growth measured by turbidity ceased immediately. Sampling was started $15 \mathrm{~min}$. later and was continued for Io min. Sufficient glucose solution (I M) was then added to bring the glucose concn. to $10 \mathrm{~mm}$, and sampling was continued for the next $35 \mathrm{~min}$. Figure I shows that within $30 \mathrm{sec}$. of adding glucose the measured activity of hexokinase increased nearly fivefold and remained at that level for the rest of the experiment. Chloramphenicol itself, at concn. up to at least Ioo $\mu \mathrm{g} . / \mathrm{ml}$., had no effect on hexokinase activity. The activity of hexokinase was apparently partially destroyed by lysis in the absence of glucose, but the presence of the sugar appeared to effect a stabilization. All experiments requiring hexokinase determinations were therefore performed by lysing cells in the presence of glucose.

The three enzymes of glucose metabolism were measured on different portions of the same culture. Samples $(0.2 \mathrm{ml}$.) of the bacterial culture were added to weighed vials previously charged with $0.2 \mathrm{ml}$. of the following solutions: tris- $\mathrm{HCl}\left(0^{\circ} \mathrm{I} \mathrm{M}\right), \mathrm{pH} 7.6$, containing lysozyme (0.I mg./ml.) and EDTA $(2.5 \mathrm{~mm})$. Unless the culture medium already contained it, glucose ( $10 \mathrm{mM}$ ) was also added to the lysozyme solution. The vials were reweighed to determine accurately the volume of bacterial culture taken and were allowed to remain at room temperature for about $\mathrm{I} \mathrm{hr}$. They were then brought to $37^{\circ}$ and substrates were added in a volume of $0.6 \mathrm{ml}$. For 6-phosphogluconate dehydrogenase the substrate solution contained 6-phospho-D-gluconic acid (tricyclohexylammonium salt) (I7 mM), $\mathrm{NADP}^{+}(\mathrm{I} \cdot 08 \mathrm{mM})$ and $\mathrm{MgCl}_{2}(\mathrm{I} \cdot 33 \mathrm{~mm})$ in $0 \cdot \mathrm{I} \mathrm{M}$-tris- $\mathrm{HCl}, \mathrm{pH} 7 \cdot 6$. For measurement of glucose 6-phosphate dehydrogenase the solution contained glucose 6-phosphate $\left(\mathrm{Na}_{2}\right.$ salt) $(33 \mathrm{mM}), \mathrm{MgCl}_{2}(\mathrm{I} \cdot 33 \mathrm{mM}), \mathrm{NADP}+(\mathrm{I} \cdot 08 \mathrm{~mm})$ and 6-phosphogluconic acid dehydrogenase $\left(0.023\right.$ enzyme units $/ \mathrm{ml}$.) in $\mathrm{o}^{\circ} \mathrm{I} \mathrm{M}$-tris- $\mathrm{HCl}, \mathrm{pH} 7 \cdot 6$. For assay of hexokinase activity the solution contained the following substances in $0^{\circ} \mathrm{I} M-$ tris- $\mathrm{HCl}, \mathrm{pH}_{7} \cdot 6$ : ATP (4 mM); NADP+ (I.08 mM); glucose (Io mM); $\mathrm{MgCl}_{2}$ (4mM); glucose 6-phosphate dehydrogenase $(0.35$ enzyme units $/ \mathrm{ml}$.) and 6-phosphogluconic acid dehydrogenase (0.01 8 enzyme units $/ \mathrm{ml}$.). Incubation was allowed to proceed for $25 \mathrm{~min}$. at $37^{\circ}$ and the reactions were terminated by adding to each vial $0.4 \mathrm{ml}$. of $0.75 \mathrm{M}-\mathrm{Na}_{2} \mathrm{CO}_{3}$. The extinctions were read at $340 \mathrm{~m} \mu$ with a Cary model 14 spectrophotometer against the appropriate blanks. In each of these reaction mixtures the enzyme under study was the rate-limiting factor; added enzymes were present in excess amounts. Preliminary experiments showed that the rate of NADPH production was almost linear for each of the enzymes for over $30 \mathrm{~min}$. Departures from linearity were not affected by twofold changes in the concentration of any of the reactants except the lysed cells. Since all the samples from a particular experiment were assayed simultaneously for the same length of time they can be considered in a comparative manner even if the true zero time rates were slightly but consistently in error. 
$\beta$-Galactosidase was also measured in weighed samples of cell suspension as described by Palmer \& Moses (1968).

In each case one enzyme unit is defined as that quantity of enzyme catalysing the production of I $\mathrm{m} \mu$ mole of measured product $/ \mathrm{min}$. at $37^{\circ}$.

Chemicals. Chloramphenicol was a gift from Parke, Davis and Co., Detroit, Michigan, U.S.A.; all other biochemicals and enzymes were from Calbiochem, Los Angeles, California, U.S.A.

\section{RESULTS}

Growth experiments. Experiments were performed to determine whether temporary exposure to glucose would facilitate metabolism of the sugar when it was again introduced into the medium. Cells of Bacillus subtilis were grown in minimal medium (I mM- $P_{i}$ ) with one of a number of carbon sources. During the period of exponential

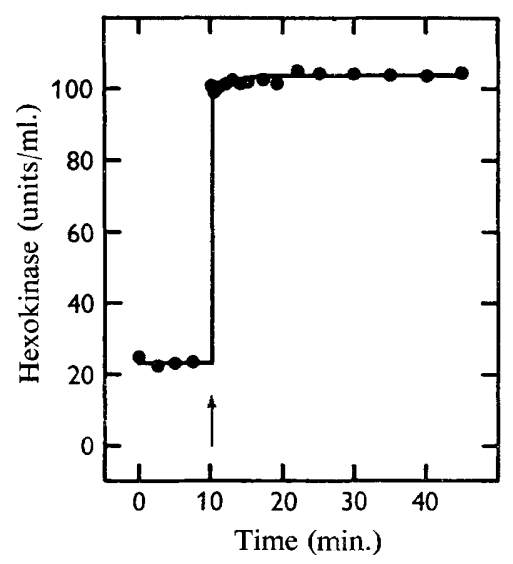

Fig. I

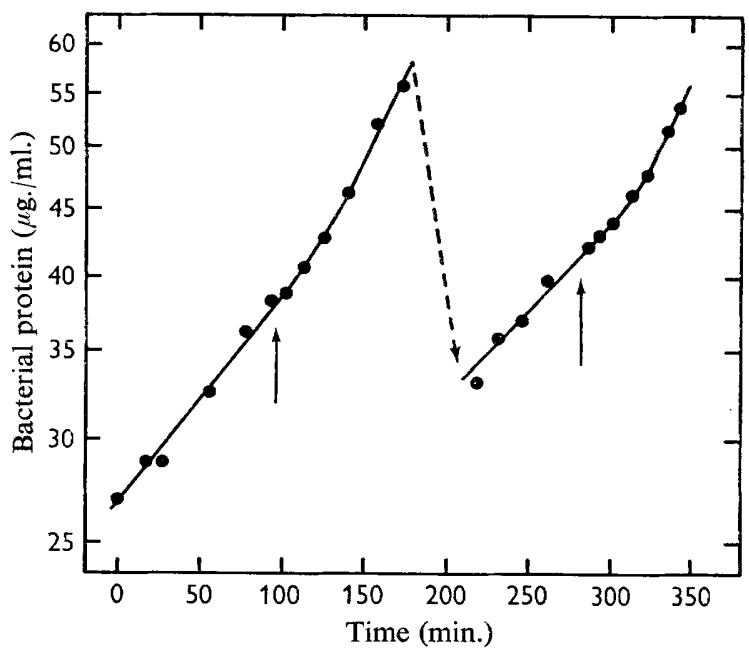

Fig. 2

Fig. I. Effect on hexokinase activity of the presence and absence of glucose during cell lysis. Cells growing on broth were treated with chloramphenicol (100 $\mu \mathrm{g} . / \mathrm{ml}$.). When growth was observed to have ceased, samples were removed at intervals into lysozyme solution without added glucose. Glucose (10 mM) was added to the culture at $10 \mathrm{~min}$. ( $\uparrow$ ) and sampling was continued. Each sample was later measured for hexokinase activity.

Fig. 2. Growth shifts from alanine to glucose. Cells growing on alanine-minimal medium were supplied with glucose at $\uparrow$. After following growth by turbidity for about $80 \mathrm{~min}$. the cells were separated from the medium and resuspended in fresh alanine-minimal medium (dashed arrow). Growth was followed to re-establish the rate on alanine and glucose was again added $(\uparrow)$. The response to glucose was observed for a further 60 min.

growth glucose (I $\mathrm{mm}$ ) was added and the growth response observed. With cells cultured on maltose no change in growth rate was obtained on adding glucose. When acetate, alanine, glycerol, proline or succinate were the initial sources of carbon the growth rate increased gradually to a new and higher rate which was reached in 60-70 min. (Fig. 2). After about one doubling in the presence of glucose the cells were filtered through a Millipore membrane filter $(0.45 \mu$ pore size), washed, and resuspended in the original medium. Growth was promptly resumed at approximately the 
rate characteristic for the original substrate. After a further doubling of the cell mass in the original substrate, glucose (Iо $\mathrm{mM}$ ) was again added. The change in growth rate on addition of this second quantity of glucose was very similar to the first: again a gradual increase in the growth rate was obtained reaching a new maximum rate in about I hr.

There is much variability in the growth response of bacteria when glucose is introduced into the medium. In some cases the effect is very rapid: in Escherichia coli, for example, a shift from glycerol to glucose is immediate at high (O.I M) concentrations of $P_{i}$, but delayed at lower concentrations (Palmer \& Moses, 1967). The present results show that adding glucose for one cell doubling to Bacillus subtilis growing on another substrate did not accelerate the second growth response to glucose after the cells had been returned to the original medium for one generation. Thus, specific enzyme synthesis did not appear to be involved in responding to glucose and the delay was more probably metabolic in origin, perhaps entailing a readjustment of the balance of intermediary metabolic pool sizes, etc. By implication, then, the cells were already adequately equipped enzymically to deal with glucose when grown on a variety of other substrates.

Support for this contention has been obtained by H. G. Ungar (unpublished work) in the course of studies on the growth-shift with Escherichia coli from acetate to glucose in media containing $5 \mathrm{~mm}-P_{i}$; this shift results in a slow (60 min.) attainment of the enhanced growth rate. Using the technique described by Prevost \& Moses (1967), Ungar studied the release of ${ }^{14} \mathrm{CO}_{2}$ from labelled glucose during the shift and showed that ${ }^{14} \mathrm{CO}_{2}$ evolution began virtually immediately (less than I min.) even in the presence of concentrations of chloramphenicol high enough to preclude any possibility of protein synthesis. Thus, glucose may enter metabolism rapidly, yet not result in an immediate increase in the growth rate.

Growth shifts. In an attempt to discover whether glucose in the medium specifically increased the content of the glucose enzymes, experiments were performed in which glucose was added to cells growing on other substrates. Since adding glucose often resulted in an increase in growth rate, other types of growth shift, not involving glucose, were investigated to determine the effect of increasing the growth rate without adding glucose.

Supplying glucose to cells growing exponentially in glutamate-minimal medium invariably resulted in a considerable $(50-60 \%)$ reduction in the differential rate of hexokinase synthesis (Fig. 3). The growth rate itself increased gradually over about $\mathrm{I}$ hr to a rate approximately double that in glutamate. Glucose did not reduce the rate of synthesis for the dehydrogenases for glucose 6-phosphate and 6-phosphogluconate. In some experiments increases in their rates of synthesis were observed, usually after a lag (Fig. 3). In other cases the increases were small enough to be insignificant.

When glucose (Io mM) was added to cells on nutrient broth hexokinase synthesis was not affected and the rates of synthesis of the above two dehydrogenases increased by up to $25 \%$ in a number of experiments (Fig. 4). There was no significant change in the growth rate.

These results suggested the possibility of a specific inducing effect by glucose on the two dehydrogenases. However, the apparent repressive effect of glucose on the rate of hexokinase synthesis in glutamate-grown cells suggested that this might be associated with an increase in growth rate rather than a specific repression of enzyme synthesis. 
Since hexokinase is the first enzyme of glucose catabolism one would expect glucose to enhance rather than reduce the rate of its synthesis. The behaviour of these three enzymes was therefore studied in shifts resulting in a marked increase in growth rate, but without using glucose to achieve this.

In one experiment glycerol (22 $\mathrm{mm}$ ) was added to cells growing exponentially in glutamate-minimal medium. Growth ceased immediately and resumed about $30 \mathrm{~min}$. later at a greatly increased rate (Fig. $5 a$ ). Glycerol is probably metabolized by an inducible enzyme system (by analogy with the situation in Escherichia coli (Hayashi \& Lin, 1965)) and the delay before growth started in glycerol may be ascribed to the necessity of inducing the glycerol enzymes. Why the addition of glycerol terminated

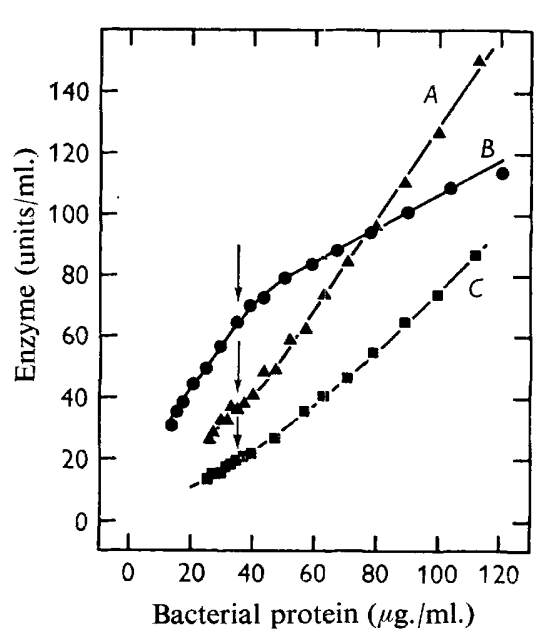

Fig. 3

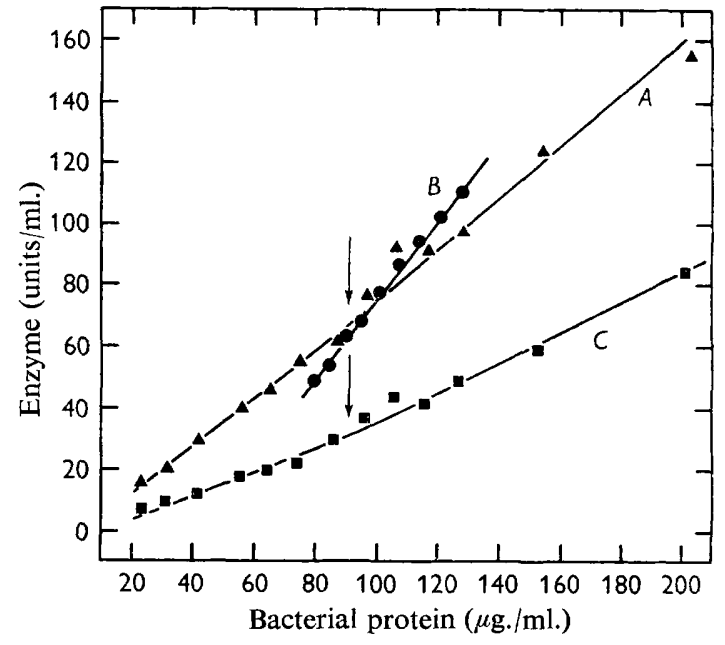

Fig. 4

Fig. 3. Effect on the synthesis of the glucose enzymes of adding glucose to cells in glutamateminimal medium. Glucose (Io mM) was added at arrows. Growth was measured by turbidity. $A$, glucose 6-phosphate dehydrogenase; $B$, hexokinase; $C, 6$-phosphogluconate dehydrogenase.

Fig. 4. Effect on the synthesis of the glucose enzymes of adding glucose to cells in broth. Glucose (IO mM) was added at arrows. Growth was measured by turbidity. $A$, glucose 6-phosphate dehydrogenase; $B$, hexokinase; $C$, 6-phosphogluconate dehydrogenase.

growth on glutamate is not understood. Shifting from growth on glutamate to growth on glutamate plus glycerol slightly depressed the synthesis of the two dehydrogenases, and reduced the rate of hexokinase synthesis to only $4 \mathrm{I} \%$ of the earlier rate on glutamate (Fig. 5). Another shift-up without glucose was performed by adding $0.5 \mathrm{ml}$. of a $50-$ fold concentrated solution $(40 \%, \mathrm{w} / \mathrm{v})$ of nutrient broth to $50 \mathrm{ml}$. of a culture growing in glutamate-minimal medium. The growth rate immediately increased threefold (Fig. 6). Both dehydrogenases showed a period of decreased synthesis lasting 32-42 min. (about one generation) after which the differential rates of synthesis recovered to $75-87 \%$ of those obtained before the introduction of broth. Hexokinase synthesis, on the other hand, was immediately reduced to $34 \%$ of the differential rate before broth and this did not alter for at least $85 \mathrm{~min}$. or two generations (Fig. 6). The transient reduction in the rates of synthesis of the two dehydrogenases is of particular interest and will be discussed below. 

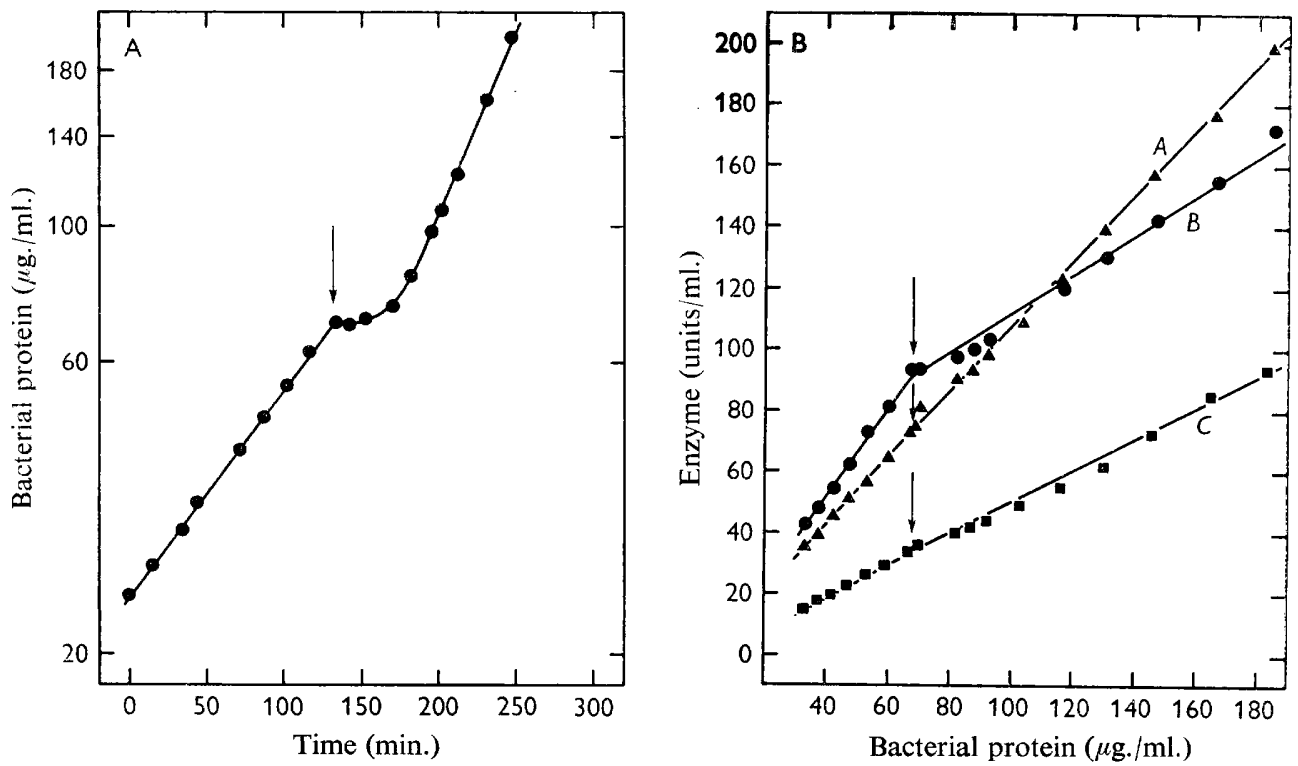

Fig. 5. Effect on growth and on the synthesis of the glucose enzymes of adding glycerol to cells on glutamate-minimal medium. Glycerol $(0.2 \%, \mathrm{w} / \mathrm{v})$ was added at the arrows. Growth was measured by turbidity. A, growth curve; $\mathrm{B}$, differential synthesis of enzymes: $A$, glucose 6-phosphate dehydrogenase; $B$, hexokinase; $C, 6$-phosphogluconate dehydrogenase.

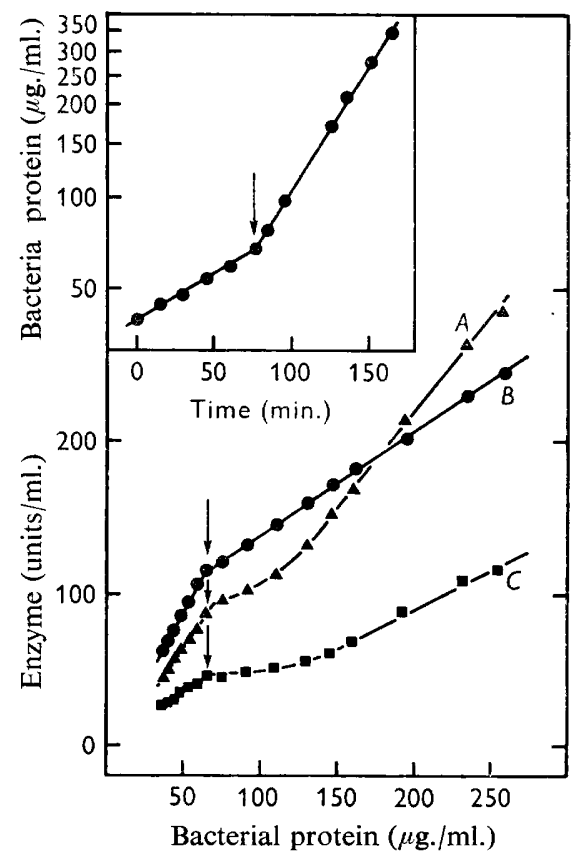

Fig. 6. Effect on growth and on the synthesis of the glucose enzymes of adding broth concentrate to cells on glutamate-minimal medium. Broth concentrate was added at the arrows. Growth was measured by turbidity. Main graph, differential synthesis of enzymes. $A$, glucose 6-phosphate dehydrogenase; $B$, hexokinase; $C, 6$-phosphogluconate dehydrogenase. Inset: growth curve. 
Steady-state levels of the three glucose enzymes. A series of measurements were made of the differential rates of synthesis of the glucose enzymes in cells which had been growing exponentially for at least three generations in a number of media. In each case cells were sampled at intervals during the subsequent $60 \mathrm{~min}$. for measurements of enzyme content. Exponential growth at an unchanged rate continued until the end of the sampling period. Table I presents the differential rates of synthesis for cells grown on broth, glucose, glutamate, glycerol, proline and succinate. The data in Table I demonstrates that the differential rate of hexokinase synthesis is characteristic of the medium rather than the growth rate per se. The growth rates in all the media except succinate-minimal were quite similar, yet the rates of hexokinase synthesis varied considerably.

For comparative purposes the differential rates of synthesis of $\beta$-galactosidase were studied in Escherichia coli ${ }_{6}^{\mathrm{c}}$ growing in the same media (except glutamate, in which it would not grow) (Table I). This strain has lost the regulator genes ( $\mathrm{i}$ and $\mathrm{o}$ ) for the lac operon (Steers et al. 1965) and the behaviour of $\beta$-galactosidase synthesis in growth shifts has been studied by Palmer \& Moses (1967). It is therefore of value in determining the pattern of biosynthesis as a function of different growth conditions for an enzyme devoid of all known regulatory mechanisms.

\section{Table I. Differential rates of enzyme synthesis in different media}

Cells were grown exponentially for several generations and samples were then removed over a 60 min period while growth was measured by turbidity. Results are expressed as enzyme units $/ \mu \mathrm{g}$. of bacterial protein and as percentages of the rates of synthesis in succinateminimal medium. Growth rates are recorded as doublings $/ \mathrm{hr}(\mu)$.

\begin{tabular}{|c|c|c|c|c|c|c|c|c|c|c|}
\hline \multirow[b]{3}{*}{ Medium } & \multicolumn{7}{|c|}{ B. subtilis } & \multicolumn{3}{|c|}{ E. coli $\mathrm{O}_{67}^{\mathrm{c}}$} \\
\hline & \multirow[t]{2}{*}{$\mu$} & \multicolumn{2}{|c|}{$\begin{array}{c}\text { Glucose } \\
\text { 6-phosphate } \\
\text { dehydrogenase }\end{array}$} & \multicolumn{2}{|c|}{$\begin{array}{c}\text { 6-Phospho- } \\
\text { gluconate } \\
\text { dehydrogenase }\end{array}$} & \multicolumn{2}{|c|}{ Hexokinase } & \multirow[t]{2}{*}{$\mu$} & \multicolumn{2}{|c|}{$\beta$-Galactosidase } \\
\hline & & Rate & $\%$ & Rate & $\%$ & Rate & $\%$ & & Rate & $\%$ \\
\hline Succinate & $0.5 \mathrm{I}$ & 0.944 & 100 & 0.653 & 100 & $2 \cdot 863$ & 100 & 0.89 & $4 I \cdot 3$ & 100 \\
\hline Proline & 0.91 & 1.075 & 114 & 0.693 & 106 & $2 \cdot 049$ & 72 & 0.28 & $39 \cdot 8$ & 96 \\
\hline Glutamate & 0.97 & $I \cdot 155$ & 122 & 0.517 & 79 & $I \cdot 517$ & 53 & - & - & - \\
\hline Broth & $I \cdot 04$ & $1 \cdot 035$ & I IO & 0.613 & 94 & $1 \cdot 326$ & 46 & $\mathrm{I} \cdot 58$ & $27 \cdot 3$ & 66 \\
\hline Glycerol & 1.03 & 0.974 & 103 & 0.653 & 100 & $I \cdot 205$ & 42 & 0.80 & $42 \cdot 7$ & 100 \\
\hline Glucose & 0.98 & $1 \cdot 075$ & 114 & 0.467 & 72 & 0.869 & 30 & 1.04 & 16.6 & 40 \\
\hline
\end{tabular}

\section{DISCUSSION}

Are the glucose enzymes constitutive?

Our knowledge of the mechanism of constitutivity in artificial mutants of systems normally inducible or repressible indicates that genetic (or true) constitutivity is the consequence of the absence or malfunctioning of a regulator system. From a practical point of view this makes it very difficult to decide whether a protein whose rate of synthesis varies but slightly under different conditions is constitutive or not. An unvarying rate of synthesis may mean simply that the conditions for varying it have not yet been discovered and not that no such variation is in principle possible.

A decision on constitutivity requires the establishment of criteria. These might be 
laid down on a rational basis by deciding, on the grounds of general experience, how a constitutive system would be expected to behave; we must, however, recognize that our general experience may not be sufficient to provide satisfactory criteria. Alternatively, one might compare the enzyme under study with enzymes in artificial mutants which have been analysed genetically and which are known to suffer impairment of the regulatory mechanism. Both approaches will be attempted with the glucose enzymes.

If the glucose enzymes are constitutive we might expect them always to form a constant proportion of the cellular protein, regardless of the culture conditions; if they are inducible it would be reasonable to expect them to be induced either separately by their immediate substrate or by glucose itself if they formed a coordinate induction system. As inducible enzymes they might nevertheless show high basal rates of synthesis in the absence of inducer. Experimental results with glucose 6-phosphate dehydrogenase and 6-phosphogluconate dehydrogenase showed them both to be present in remarkably constant amounts irrespective of growth conditions (Table I). While this suggests that these enzymes are constitutive, the fact that in some experiments there were weak responses to the presence of glucose argues that some regulatory control might be possible. The difficulty in making a decision originates from a number of considerations. It is difficult in principle to prove a negative case (the absence of direct regulation), yet evidence for the positive case is not convincing. One can only guess at the identity of a postulated inducer and no progress towards its identification can be made unless clear evidence is obtained that the system is indeed inducible. The gross intracellular pool sizes of likely inducers have not been measured under different growth conditions, but even were this to be done it would have only limited value, since the local concentration of a metabolite at a regulatory site may not of necessity be correlated with its over-all intracellular abundance.

Similar difficulties exist with hexokinase. This enzyme was also found to be present at all times and subject to no more than a threefold variation in activity. Glucose itself would seem to be the most probable inducer, yet its presence in the medium actually decreased hexokinase synthesis and the highest rates of formation were observed when growth took place on substrates far removed metabolically from glucose. We must therefore admit that the behaviour pattern of a naturally constitutive enzyme under varying growth conditions is not readily predictable and it is not possible to decide from the arguments presented above whether or not the three enzymes studied here are under regulatory control.

Arguments based on analogy with a known constitutive system result in a more definite conclusion but it is difficult to assess their validity. For our comparisons we have used the formation of $\beta$-galactosidase in Escherichia coli strain $\mathrm{o}_{67}^{c}$. Constitutivity of the lac enzymes in E. coli is of two types (Jacob \& Monod, 196r); regulator mutants $\left(i^{-}\right)$fail to make a fully functional repressor, while operator constitutives $\left(o^{c}\right)$ fail to respond to normal repressor. Strain $\mathrm{o}_{67}^{\mathrm{c}}$ is deleted for both the regulator and operator genes, and is thus fully constitutive on both counts. The formation of $\beta$-galactosidase in this strain was studied by Palmer \& Moses (1967) and from the response to glycerol to glucose growth shifts and to the presence of certain inhibitors it was concluded that the synthesis of the enzyme might indeed be totally devoid of regulation in this strain. The rates of enzyme synthesis were different in glycerol and glucose but it was suggested that this was due not to a specific type of catabolic repression modulated outside the 
lac operon, but rather to a rearrangement of the overall macromolecular composition of the cell under different growth conditions. In that study and in the present one enzyme synthesis is reported on a differential basis, i.e. as a proportion of total protein synthesis. If there is a large change in the synthetic rates for other proteins, with little or no change for the enzyme under study, then the proportion of the whole represented by the particular enzyme (the differential rate of synthesis) will be observed to change.

Table I shows that $\beta$-galactosidase synthesis in $E$. coli $\mathrm{O}_{67}^{\circ}$ and hexokinase synthesis in Bacillus subtilis both show a $2 \cdot 5-3$-fold change in rate in five different media. For both enzymes synthesis is most rapid on succinate and least rapid on glucose. Differences exist between the two systems on the other three substrates, and it is, of course, impossible to compare the two cases too closely, since different organisms are involved. The point is that in both cases variations of similar degrees of magnitude exist in response to growth in a number of media. The dehydrogenases do not show such variability.

Another interesting comparison is found in the kinetics of enzyme synthesis during growth shifts. With wild-type strains of Escherichia coli, inducible for the lac operon, a transient inhibition of $\beta$-galactosidase synthesis is observed during shifts from glycerol, succinate or maltose to glucose (Moses \& Prevost, 1966), acetate to glucose (H. G. Ungar, unpublished work), and glycerol to broth (J. Palmer, unpublished work). In strain $o_{67}^{c}$, on the other hand, no such transient repression of $\beta$-galactosidase is observed in glycerol to glucose shifts, although the final rate of enzyme synthesis is lower in glucose than in glycerol (Palmer \& Moses, 1967). The behaviour of the two dehydrogenases and hexokinase, reported in the present communication, may also be distinguished in this way. Both dehydrogenases showed marked transient inhibition when the cells were shifted from glutamate into broth (Fig. 6), and a slight effect was also obtained in a shift from glutamate to glucose (Fig. 3); hexokinase showed no transient repression under these conditions, but rather a simple change to a lower rate of synthesis, exactly as observed with $E$. coli $\mathrm{O}_{67}^{\circ}$.

It seems, then, admitting all the disadvantages of analogy arguments, that a tentative conclusion might be reached that hexokinase synthesis is truly constitutive while the appearance of constitutivity for the dehydrogenases is the result of precise efforts on the part of the cell to regulate the biosynthesis of these two enzymes.

This investigation was sponsored by the United States Atomic Energy Commission.

\section{REFERENCES}

Brown, D. D. (1961). Cold Spring Harb. Symp. quant. Biol. 26, 254.

HaRtwell, L. H. \& MAgasaniK, B. (1963). The molecular basis of histidase induction in Bacillus subtilis. J. molec. Biol. 7, $40 \mathrm{r}$.

HAYASHI, S. \& Lin, E. C. C. (1965). Capture of glycerol by cells of Escherichia coli. Biochim. biophys. Acta 94, 479.

JACOB, F. \& MONOD, J. (I96I). Genetic regulatory mechanisms in the synthesis of proteins. J. molec. Biol. 3, 3 I 8 .

Karström, H. (1930). Über die Enzymbildung in Bakterien. Thesis, Helsinki.

Magasanik, B. (I96I). Catabolite repression. Cold. Spring Harb. Symp. quant. Biol. 26, 249.

MANDELSTAM, J. (1962). The repression of constitutive $\beta$-galactosidase in Escherichia coli by glucose and other carbon sources. Biochem. J. 82, 489 .

Moses, V. (1967). The regulatory process in the de-repression of enzyme synthesis. Alkaline phosphatase of Bacillus subtilis. Biochem. J. 103, 650. 
Moses, V. \& Prevost, C. (1966). Catabolite repression of $\beta$-galactosidase synthesis in Escherichia coli. Biochem. J. 100, 336.

Palmer, J. \& Moses, V. (1967). Involvement of the lac regulatory genes in catabolite repression in Escherichia coli. Biochem. J. 103, 358.

PALMER, J. \& MOSES, V. (I968). The role of the regulator-gene product (repressor) in catabolite repression of $\beta$-galactosidase synthesis in Escherichia coli. Biochem. J. ro6, 339.

PARdeE, A. B. \& BeCKwIth, J. R. (1963). Control of constitutive enzyme synthesis. In Informational Macromolecules. Ed. by H. J. Vogel, V. Bryson and J. O. Lampen, p. 255. New York and London: Academic Press, Inc.

Pardee, A. B. \& Prestidge, L. S. (I96I). The initial kinetics of enzyme induction. Biochim. biophys. Acta 49, 77.

Prevost, C. \& Moses, V. (I967). Pool sizes of metabolic intermediates and their relation to glucose repression of $\beta$-galactosidase synthesis in Escherichia coli. Biochem. J. ro3, 349.

Steers, E., Jun., Craven, G. R. \& Anfinsen, C. B. (I965). Comparison of $\beta$-galactosidases from normal $\left(i^{-} o^{+} z^{+}\right)$and operator constitutive $\left(i^{-} o^{\mathrm{c}} z^{+}\right)$strains of E. coli. Proc. natn. Acad. Sci., U.S.A. 54, 1174 . 